\title{
Australia and Western European Integration in the 1950s
}

\author{
Andrea BENVENUTI
}

This article examines Australia's attitude towards the process of Western European integration in the 1950s. In particular, it focuses on the responses of Robert Menzies' Liberal-Country Party Coalition government to the establishment of the European Coal and Steel Community (ECSC) in 1951-1952, the ill-fated experiment of the European Defence Community (EDC) in 1952-1954 and the creation of the European Economic Community (EEC) in 1957-1958. The article argues that while superficially supportive of steps towards greater Western European integration, the Australian authorities adopted an ambivalent attitude towards it. Policymakers in Canberra recognized the importance of an economically prosperous and politically cohesive Western Europe. At an economic level, an affluent Western Europe could offer greater trading opportunities to Australian exporters. At a political level, a strong Western European bloc could not only help consolidate the Western camp amidst growing Cold War tensions, but it could also provide a valuable bulwark against Soviet communism. What is more, it could play an important part in buttressing British power in world affairs. The Australian view was that unless Britain's 'continental backdoor' was secured, London's ability to play a major defence role outside Europe would be curtailed. Australian policymakers were mindful of Britain's wartime 'beat-Hitlerfirst' strategy and knew that in the event of an acute crisis in Europe, the British government would inevitably concentrate its efforts on the defence of the British Isles at the expense of Commonwealth commitments in the Far East.

Yet, the formation of a strong Continental grouping also posed a number of major challenges to the makers of post-war Australian foreign policy. As this article aims to show, the Menzies government soon began to wonder whether attempts to create supranational bodies in Continental Europe accorded with Australian political, economic and security interests. Australian concerns were specifically centred on the possibility of Britain becoming too closely associated with the nations of the 'Little Europe' (France, Italy, the Benelux and West Germany) and the implications that such a move would have on Commonwealth cohesion and on London's capacity to continue to play a major role in Asia, upon which Australia's security relied. A further concern was the economic damage that Australia was expected to suffer should Britain decide to join the EEC: Britain's membership of the EEC would not only wreck the imperial preferential system that had regulated Commonwealth commerce since 1932, but it would also introduce new impediments to Australian trade with Britain.

Australia's attitude towards the EEC and its successor, the European Union (EU), has received extensive treatment from the historians of Australia's foreign relations. There is now a large body of literature on the EEC/EU-Australian relationship. Studies in this area have generally dealt with two distinct phases of the relationship: the first phase centres on Australian policy towards the British efforts to join the Community in 1961-72 as well as on the likely impact of Britain's entry on the traditionally 
intimate Anglo-Australian ties. Here the EEC constitutes the background, rather than the focus, which remains firmly set on Canberra's responses to London's European policy. ${ }^{1}$ The second phase has as a starting point Britain's accession to the EEC in 1973, but concentrates on Australian attempts to develop a constructive relationship with the EEC/EU despite significant differences on trade and agricultural issues. The focus here is no longer on Anglo-Australian diplomacy over the EEC question, but Canberra's policy towards the EEC/EU itself. ${ }^{2}$ The period from the 1960s onward is now well-documented, while very little has been said about Australian responses to the incipient process of Western European integration in the 1950s. The only notable exception has been John O'Brien's work on the attitude of the Australian Department of Trade towards the EEC between 1956 and 1961. ${ }^{3}$ This article builds on O'Brien's work, but it casts its net wider to include Australian responses to the ECSC and EDC. In so doing, it not only focuses on Canberra's perceptions of the likely economic impact of Western European moves towards greater Continental integration on Australia, but it also deals with the broader political and strategic questions that such moves raised for the Australian government.

1. See S. WARD, Australia and the British Embrace: The Demise of the Imperial Ideal, Oxford University Press, Melbourne, 2001; H.G. GELBER, Australia, Britain and the EEC, 1961 to 1963, Oxford University Press, Melbourne, 1966; A. BENVENUTI, Australia and the 'Turn to Europe', 1961-72, Boydell \& Brewer, New York, 2008; N.P. LUDLOW, Too Far Away, Too Rich and Too Stable: The EEC and Trade with Australia during the 1960s, in: Australian Economic History Review, 3(2001), pp.267-286; D. GOLDSWORTHY, Menzies, Macmillan and Europe, in: Australian Journal of International Affairs, 2(1997), pp.157-169; J. O'BRIEN, The British Commonwealth and the European Economic Community, 1960-1963: The Australian and Canadian Experiences, in: Round Table, 340(1996), pp.479-491; P. ROBERTSON, J. SINGLETON, Britain, the Dominions and the EEC, 1961-1963, in: A. DEIGHTON, A.S. MILWARD (eds.), Widening, Deepening and Acceleration: The European Economic Community 1957-1963, Nomos, Baden-Baden, 1999, pp. $107-122$.

2. See A. BENVENUTI, Australia's Battle Against the Common Agricultural Policy: The Fraser Government's Trade Diplomacy and the European Community, in: Australian Journal of Politics and History, 2(1999), pp.181-196; A. BENVENUTI, Australian-European Negotiations on Agriculture: A Study in Economic Diplomacy 1983-1993, Monash University, MA Thesis, 1997; A. BENVENUTI, The Howard Government's Diplomacy towards the European Union on Agriculture: An Early Assessment, in: Political Expressions, 1(1998); A. BURNETT, Australia and the European Communities in the 1980s, Australian National University, Canberra, 1983; A. ELIJAH, P. MURRAY, C. O'BRIAN, Divergence and Convergence: The Development of European Union-Australia Relations, in: CERC Working Papers Series, 3(2000), pp.1-49; P. MURRAY, Australia and the European Union, in J. COTTON, J. RAVENHILL (eds.), Seeking Asian Engagement, Oxford University Press, Melbourne, 1997, pp.230-247; P. MURRAY, Australian and the European Superpower: Engaging with the European Union, Oxford University Press, Melbourne, 2005.

3. J. O'BRIEN, Australian Department of Trade and the EEC, 1956-61, in: A. MAY (ed.), Britain, the Commonwealth and Europe: The Commonwealth and Britain's Application to Join the European Communities, Palgrave, Basingstoke, 2001, pp.39-52. 


\section{Australia and the ECSC}

On 26 June 1950, in his Roy Milne memorial lecture to the Australian Institute of International Affairs in Adelaide, Australia's newly-elected Liberal Prime Minister, Robert Menzies, articulated his vision for the British Commonwealth in the world of the $1950 \mathrm{~s} .{ }^{4}$ A strong and tightly-knit Commonwealth, he said, had the potential to play an important role in international affairs: not only would it strengthen the voice of its members within the emerging Western alliance, but it would also bolster the latter in its efforts to contain the Soviet threat. In so doing, it would make a significant contribution to Western and Australian security. But for the Commonwealth to achieve these objectives and pull its proper weight in international affairs, greater foreign policy coordination among its members was needed. For Menzies, Western Europe was a good case in point. 'If the British Commonwealth is to be regarded merely as a series of separate even if respectable fragments', he argued,

'then inevitably the settlement of Europe will tend to become a contest between the Soviet Union on the one hand and the United States on the other, with the European powers little more than pawns in the game, and with Great Britain acting more or less precariously as an intermediary'.

On the contrary, 'if the Commonwealth countries co-operate', he added, 'then they can not only alter the character of the contest, but can make an immense contribution to European peace'. As he explained,

'It is, I believe, essential to the welfare of Europe and therefore of mankind that the British voice in the European Settlement should be both strong and clear. For if the United Kingdom is to speak only for itself [...] it will suffer inevitably from what Kipling called the 'webbed and inward-turning eye', and what should be a settlement will tend to become an old-fashioned bilateral contest between the Communist autocracy of Russia and the democratic Capitalism of the United States'.

For Menzies, it was 'unlikely that there will be a good and lasting European settlement without a vital and powerful contribution from her'. Hence, Britain, in collaboration with its Commonwealth partners, should not shy away from 'accept[ing] direct and primary European responsibilities'. Menzies appeared unconcerned that, by seeking a greater European role, London could become increasingly drawn into a European orbit and thus be forced to make an unwelcome choice between the British Commonwealth and a Western European union. This, he said, was a false problem for 'it seems to assume that the British Dominions have no vital concern with Europe'. Quite the contrary, he argued, Australia had every interest in seeing the emergence of a strong and resilient Western Europe, which he regarded as 'the frontier in any crucial

4. R. MENZIES, The British Commonwealth of National in International Affairs, Roy Milne Memorial Lecture, 26.06.1950 available at http://www.menziesvirtualmuseum.org.au/ transcripts/ Speech_is_of_Time/ print/101_BritCwlthInt.pdf [accessed on 24 July 2009]. See also A. WATT, The Evolution of Australian Foreign Policy, 1938-1965, Cambridge University Press, Cambridge, 1967, pp.275-276.

5. R. MENZIES, op.cit. 
fight' in the emerging Cold War. 'We of the King's Dominions', as he put it, 'have an interest in Europe, out of which the two great wars of our history have come'. ${ }^{6}$

Menzies' goal of a strong and prosperous Western Europe, founded on a close political and economic partnership between Britain and its Continental allies, was clearly premised on the assumption that any future Anglo-European collaboration would not come at the expense of Commonwealth unity, but that it would rather take place with Commonwealth concurrence. What Menzies envisaged was essentially greater inter-governmental co-operation between Britain and its European partners. He had no wish for greater Western European political and economic integration. In late December 1949 the Department of Commerce and Agriculture (DCA) set limits beyond which no Australian government should go in supporting Western European co-operation. In a paper drafted immediately after Menzies' victory in the 1949 federal election, officials in the DCA made it clear that while Australia had taken an active interest in attempts to further Continental collaboration as embodied by the Brussels Pact (1948), the Organisation for European Economic Cooperation (1948) and the Council of Europe (1949), the chief aim of its European policy was 'to ensure as far as possible that [its] interests in the UK market are maintained and safeguarded'. Australian efforts, therefore, were to be directed to monitor closely 'actual and anticipated developments in Europe' and influence as far as possible such developments 'in a direction consonant with Australia's interests'. According to the DCA, 'full scale economic integration among even some of the countries of Western Europe' could be safely ruled out in the short and medium term. At any rate, British attitude towards European co-operation was described as 'reassuring' from the viewpoint of Australia's economic interests. In spite of this, it was nonetheless worthwhile to seek, from time to time, a 're-statement of her attitude by the United Kingdom in British Commonwealth discussions'. Australian policy, officials in the DCA concluded, was not to 'question the United Kingdom's participation in moves towards closer economic partnerships among the countries of Western Europe'. Rather, it was to remind London that there were reciprocal obligations among Commonwealth partners and that

'any proposal in the field of Western European "integration" which affect the United Kingdom's trade might also affect Australia experts of particular commodities to the United Kingdom'?

In this, the policy of the new Liberal-Country Party Coalition administration did not differ appreciably from that of its Labor predecessor. In 1948 Ben Chifley's Labor government had rejected a British proposal for the creation of a Western Union, which Foreign Secretary Ernest Bevin had unveiled in an address to the House of Commons on 22 January 1948. Although it was couched in idealistic language and carefully avoided any specific detail, Bevin's 'Western Union' concept represented an ambitious plan for the political, economic and military reorganisation of post-war Western

6. Ibid.

7. The National Archives of Australia, Canberra (henceforth NAA), A1838, 81/3, Notes on Moves towards European Economic Integration in relation to Australia's Export Interests, 29.12.1949. 
Europe ${ }^{8}$ For the Australian Labor government, however, the British plan had serious shortcomings and, unsurprisingly, Canberra viewed it with concern. Labor's anxiety derived principally from the fact that, with its anti-Soviet overtones, Bevin's initiative not only risked putting paid to any remaining hope of a continuing collaboration among the victors of the Second World War. It also threatened to undermine the United Nations and entrench East-West divisions across Europe. What is more, Bevin's emphasis on Western European security implied a British preference for a 'Europe-first' strategy at the expense of Asian commitments, and this could hardly please Chifley and his vocal Minister of External Affairs, Herbert Evatt.

As if this was not already enough, Bevin's 'grand design' had also the potential to affect Australian exports to the British market since it seemed to indicate London's growing interest in the creation of a European customs union. ${ }^{9}$ The Chifley government worried that a British participation in a Continental customs union would either undercut the Commonwealth preference system or impose new tariffs on Commonwealth agricultural produce. ${ }^{10}$ In 1947-48 the British market still absorbed $38 \%$ of Australia's total exports and policymakers in Canberra had no wish to see access to Australia's largest market curtailed. ${ }^{11}$ In the end, Bevin's ambitious initiative produced only limited results. In March 1948 London successfully negotiated the Brussels Treaty with France and the Benelux countries, but this Western European defence scheme was soon superseded by the Atlantic Pact in April 1949. ${ }^{12}$ In the economic field, talks on a European customs union petered out in 1948 but, in any case, the British government had already given a pledge to its Commonwealth partners that it would consider joining such a scheme only if terms were satisfactory to the Commonwealth. ${ }^{13}$

It is doubtful that the Menzies government, troubled as it was by the threat posed by international communism, would have come out so strongly against Bevin's 'Western Union' concept. After all, Bevin's plan was no blueprint for a federal Western Europe or for the establishment of supranational Western European institutions; and,

8. In Bevin's intentions, the Western Union was expected to include France, the Benelux, the nations of Scandinavia, Portugal, Italy and Greece. See G. WARNER, The Labour Governments and the Unity of Western Europe, 1945-51, in: R. OVENDALE (ed.), The Foreign Policy of the British Labour Governments, 1945-51, Leicester University Press, Leicester, 1984, pp.66-67. For the Australian Labor government's rejection of the Western Union concept see C. WATERS, The Empire Fractures: Anglo-Australian Conflict in the 1940s, Australian Scholarly Publishing, Melbourne, 1995, pp.110-111.

9. Ibid.; J. SINGLETON, P. ROBERTSON, Economic Relations between Britain and Australasia, 1945-1970, Palgrave Macmillan, Basingstoke,2002, pp.148-149; G. WARNER, The Labour Governments ..., op.cit., pp.66-67.

10. J. SINGLETON, P. ROBERTSON, Britain and Australasia, op.cit., p.149.

11. NAA, A1838, 81/3, Notes on Moves towards European Economic Integration in relation to Australia's Export Interests, 29.12.1949.

12. For the establishment of the Brussels Treaty see A. VARSORI, Il Patto di Bruxelles (1948) tra Integrazione Europea e Alleanza Atlantica, Bonacci, Rome, 1988; see also A. BULLOCK, E. Bevin, Foreign Secretary 1945-51, W. Heinemann, London, 1983, pp.529-531, 536-537, 554-555 and 567-568.

13. J. SINGLETON, P. ROBERTSON, Britain and Australasia, op.cit., p.150. 
as his Milne lecture in June 1950 indicated, Menzies was not opposed to diplomatic initiatives that would strengthen Western Europe political, economic and military cooperation on intergovernmental basis in spite of the DCA's hard-nosed approach to Continental economic developments. Yet, the proposal unveiled by French Foreign Minister Robert Schuman on 9 May 1950 for the integration of Western Europe's coal and steel industries, and the setting up of a supranational high authority tasked with overseeing the whole process, signalled a new approach to European co-operation and contained supranational elements that the Australian authorities would find in future hard to countenance. In the spring of 1950, however, the supranational character of the Schuman initiative did not seem to worry Canberra. On the contrary, the Menzies government welcomed it wholeheartedly. In an interview to Agence France Presse in mid-May, Minister of External Affairs Percy Spender described the Schuman Plan as 'one of the most constructive and hopeful steps taken since the initiation of the Marshall Plan by the United States'. According to Spender, it was not only 'a step which gives reality to the concept of European economic co-operation', but it was also 'a statesmanlike gesture towards Germany'. In remarking that economic cooperation within the Organisation for European Economic Cooperation (OEEC) had only 'made a very slow progress', Spender congratulated the French government for taking 'such important initiative in the right direction'. In Spender's view, French leadership 'will give great encouragement to all those who have been striving to secure a greater degree of co-operation in Europe both in the economic and political fields, and should therefore be of assistance to the Council of Europe and to the OEEC'. ${ }^{14}$

Spender's positive response to the Schuman Plan and its supranational character could be in part attributed to the fact that the Menzies government had nothing to fear from it. Integration of Western Europe's coal and steel industries posed no threat to Australia's commercial interests. Nor did it jeopardise Commonwealth ties. Canberra was well aware of the Attlee government's opposition to a British participation in supranational schemes. In early June 1950 the Commonwealth Relations Office (CRO) reiterated Britain's position in a despatch to the Australian and other Commonwealth governments. In it, the CRO informed its partners that although it welcomed the Schuman initiative, the British Cabinet found it impossible to associate itself with it on the terms proposed by the French government. ${ }^{15}$ Ministers and officials in London felt that no British government could subscribe to the supranational

14. NAA, A1838, 81/3/3 part 1, J.L. Mulroney (Australian High Commission Dublin) to Secretary of the Department of External Affairs (henceforth DEA), 16.05.1950.

15. Ibid., Commonwealth Relations Office to DEA, telegram A 72, 03.06.1950. 
aspects of the Schuman proposal nor commit itself to such an ambitious plan without being able to assess its political and economic implications. ${ }^{16}$

Negotiations among six Western European nations began in earnest. In late June 1950 the representatives of France, West Germany, Italy, Belgium, the Netherlands and Luxembourg gathered in Paris to trash out a compromise. By mid-December 1950, a first draft accord was completed and the final treaty establishing the ECSC was signed on 18 April 1951. ${ }^{17}$ Throughout and after the negotiations, the Australian attitude remained supportive. However, as the ratification process progressed slowly between 1951 and 1952, the Australian authorities became increasingly sceptical about the likelihood of the ECSC treaty being implemented. In January 1952 officials within the Western European sub-section of the Department of External Affairs (DEA) argued that 'it is not easy to be optimistic about the prospects for European integration'. The DEA could not fail to notice that

'the attitude of self-interest and scepticism is typical of the European States participating in these plans. France is interested in European integration as a means of offsetting Germany supremacy; Germany because both the Schuman and the Pleven Plans are stepping stones on the way back to what she considers her rightful position as the leading Power in Europe; Italy because she hopes that the Schuman Plan will help to support her backward industries and Belgium and Luxembourg, who are the least enthusiastic of the 6 members countries, still remain to be completely convinced of the advantages to be gained for themselves'.

The fact that, in the meantime, the Six had embarked upon another ambitious initiative - that of establishing a European Defence Community - did not seem to reassure External Affairs. DEA officials felt that

'even if ratification does take place it is extremely doubtful whether either of these plans will ever progress as far as the federal or semi-federal state. Once German divisions have been formed the "raison d'être" for the European army will have disappeared and once the Schuman Plan has brought about a lowering of tariffs within the community one of its main objectives will have been achieved'. ${ }^{18}$

They concluded that 'except in face of an extreme emergency European integration appears as chimerical as ever'. ${ }^{19}$ The judgment was somewhat harsh. By mid-1952 the ratification process had been completed and the ECSC had come into force in July 1952. While it may not have been startling, progress towards greater Western Euro-

16. See the National Archives, Kew, (henceforth UKNA), CAB 195/8, CM34(50), Integration of French and German Coal and Steel Industries, 02.06 .1950 and CAB 128/17, CM(50)34th conclusions, 02.06.1950; see also A. A. BULLOCK, op.cit., p.780; W. KAISER, Using Europe, Abusing the Europeans: Britain and European Integration, 1945-1963, Macmillan, London, 1996, p.21. For the British attitude towards the ECSC see J. YOUNG, The Schuman Plan and British Association, in: J. YOUNG (ed.), The Foreign Policy of Churchill's Peacetime Administration, 1951-1955, Leicester University Press, Leicester, 1988, pp.109-131.

17. W. KAISER, op.cit., p. 21

18. NAA, A1838, 81/3/3 part 4, The Schuman Plan and the European Army: Note by the European Subsection, 25.01.1952.

19. Ibid. 
pean co-operation was real. Yet, it was also painstakingly slow and it was clear that in the early 1950s the Australian government expected no sudden acceleration in the European integration process. This factor, coupled with continuing British scepticism towards supranational schemes, ensured that European affairs remained of secondary importance in Australian eyes. With the deepening of the Cold War following the outbreak of the Korean War in June 1950, Canberra's attention became increasingly focused on East and Southeast Asian issues.

\section{Australia and the EDC}

Following the successful negotiation of the Treaty of Paris, the six members of the 'Little Europe' embarked on an even bolder plan - the creation of a supranational Western European defence scheme. This scheme had originated from a proposal put forward by French Prime Minister René Pleven on 23 October 1950. It sought to integrate the newly-created West German state into Western defence structures. ${ }^{20}$ In doing so, the French authorities aimed to control and slow down what they saw as the inevitable rearmament of West Germany. The idea of rearming France's former enemy was rather unappealing to the leaders of the French IV Republic. Yet, with the Truman Administration insisting on the full rehabilitation of West Germany on grounds that a permanently weak West German state was not in the West's interests, the Pleven government felt it had little choice. It knew that if France insisted on being unhelpful, Washington could not only hold back much-needed American financial support to France, but it could also override French opposition by integrating German units into those American forces deployed on German soil. Hence, policymakers in Paris soon came to the conclusion that it was in France's interest to come up with a plan that, while allaying French fears of a German rearmament, would meet American demands. ${ }^{21}$ Talks on the French plan began in 1951 between France and its five Continental partners and were successfully concluded in Paris in May 1952 with a treaty establishing the European Defence Community. However, the ink was barely dry on the EDC treaty that the scheme began to run into trouble. While the Benelux countries ratified the treaty expeditiously, the French and Italian authorities delayed ratification. Growing opposition in France to the treaty and domestic distractions in

20. See for instance M. TRACHTENBERG, A Constructed Peace: The Making of the European Settlement, 1945-1963, Princeton University Press, Princeton, 1999, pp.110-111. See also E. FURDSON, The European Defence Community: A History, Macmillan, London, 1980.

21. On French attitudes towards West German rearmament see for instance J.-C. ALLAIN, P. GUILLEN, G.-H. SOUTOU, e.a., Histoire de la Diplomatie Française, vol.II: De 1915 à Nos Jours, Perrin, Paris, 2007, pp.389-393; see also W. HITCHCOCK, France Restored: Cold War Diplomacy and the Quest for Leadership in Europe, 1944-1954, University of North Carolina Press, Chapel Hill, 1998, pp.142-147 
Italy made it politically difficult for the two Latin governments to push it through their national parliaments. ${ }^{22}$

Australian responses to the creation of the EDC and its increasingly problematic ratification process remained muted. Australian posts in Western Europe duly reported back to Canberra on EDC developments, but ministers and official took little notice of them. ${ }^{23}$ In an appreciation of Australia's defence policy, Australian defence planners noted how the strengthening of NATO in the early 1950s and the signing of the EDC treaty had 'resulted in Russia being confronted with a very real obstacle to further territorial expansion in Western Europe, without recourse to global war'. Yet, as they hastened to add, it was NATO 'the only existing effective organisation for co-ordinating the efforts of the non-communist nations' ${ }^{24}$ But apart from this, Australian records reveal very little on the Menzies government's approach to the EDC.

This is not at all surprising if one considers that the British Conservative government led by Winston Churchill had shown no interest in joining the EDC, and that the ratification process remained stalled in the French and Italian parliaments. ${ }^{25}$ In relation to British policy towards the EDC, unless London joined this revolutionary defence scheme, there was no cause for Australian concern. While aware that Europe remained Britain's main security perimeter, Australian authorities were reassured that London had made no long-term troop commitments to Western European security. ${ }^{26}$ As for the ratification issue, Australian officials wondered whether the EDC

22. On growing French opposition to the EDC see ibid., pp.170-185. For the Italian responses to the EDC initiative see A. VARSORI, L'Italia nelle Relationi Internazionali dal 1943 and 1992, Laterza, Bari, 1998, pp.105-111; S. ROMANO, Guida alla Politica Estera Italiana: Da Badoglio a Berlusconi, Rizzoli, Milan 2004, pp.85-88; G. MAMMARELLA, P. CACACE, La Politica Estera dell' Italia: Dallo Stato Unitario ai Giorni Nostri,

Laterza, Bari, 2006, pp.190-199; etc. There are, however, significant differences between the Italian and French responses to the EDC. In a nutshell, while French opposition to the EDC was principally motivated by fear of West German rearmament as well as of loss of sovereignty in the strategically important defence field, Italian reluctance to ratify the EDC treaty was attributable to the convergence of a number of domestic political developments.

23. For diplomatic despatches on the EDC question see the following files: NAA, A816, 14/301/701; A816, 19/301/1242; A1838, 67/1/1 part 4; A1838, 78/6 part 1, A1838, 78/6 part 4.

24. NAA, A1209, 1957/4152, Defence Committee Report: A Strategic Basis of Australian Defence Policy. Attachment to Defence Committee Minute 368/1952, 08.01.1953.

25. On the Churchill government's approach to the EDC question see J. YOUNG, Churchill's "No" to Europe: The "Rejection" of European Union by Churchill's Post-War Government, 1951-1952, in: The Historical Journal, 4(1985), pp.923-937; see also A. DEIGHTON, The Last Piece of the Jigsaw: Britain and the Creation of the Western European Union, in: Contemporary European History, 2(1998), pp.181-196; S. DOCKRILL, Britain's Policy for West German Rearmament, Cambridge University Press, Cambridge, 1991, pp.140-150; K. RUANE, Agonising Reappraisals: Anthony Eden, John Foster Dulles and the Crisis of European Defence, 1953-1954, in: Diplomacy and Statecraft, 4(2002), pp.151-185

26. According to Saki Dockrill, the decision taken by the Attlee government in March 1950 to raise the strength of the British Army on the Rhine (BAOR) by two (infantry) divisions signalled a 'clear shift in Britain's global strategy from the Middle East to Western Europe'. By 1952 Britain deployed four divisions in West Germany. S. DOCKRILL, Retreat from the Continent? Britain's Motives for Troop Reductions in West Germany, 1955-58, in: Journal of Strategic Studies, 3(1997), p.49. 
would ever come into existence. 'It is not yet known', a DEA note pointed out in October 1952, 'when [the ratification process] is likely to be completed' ${ }^{27}$ The EDC debate in France, they observed a few months later, was bound to be 'prolonged and bitter', and divisions were 'more marked than ever'. It remained, therefore, to be seen whether the supporters of the treaty would be able to secure the necessary parliamentary majority of 314 votes to see it through the French Assembly. As for Italy, officials noted that there would 'be considerable opposition from the left' once the government brought the EDC bill to parliament; yet, this 'should have a successful passage' ${ }^{28}$

In mid-1954, however, the EDC's fate appeared doomed. In his first address to the French National Assembly on 17 June 1954, Prime Minister Pierre Mendès France urged political parties to overcome their divisions and find a solution to the EDC impasse that could be supported by a parliamentary majority. ${ }^{29}$ Despite Mendès France's efforts, no such solution could be found. On 30 August 1954, the National Assembly rejected the EDC treaty with a procedural motion by 319 votes to $264 . .^{30}$ The EDC fiasco plunged the question of West German rearmament into chaos and threatened to open a serious rift within the Atlantic alliance. A solution was eventually found in October 1954 when the Eisenhower Administration and its Western European allies agreed to accept West Germany as a full member of both NATO and the Brussels Pact (now renamed Western European Union). Agreement was made possible by the Churchill government's pledge to maintain four British divisions on the Continent. ${ }^{31}$ British Foreign Secretary Anthony Eden described his government's decision as 'a very formidable step to take' for a country that had so far avoided making long-term commitments to Continental defence. ${ }^{32}$

27. NAA, A1838, 78/6 part 1, Western European Integration, October 1952.

28. Ibid., Note for the Minister: Ratification of European Defence Community, 1953.

29. V. GAVIN, Power through Europe? The Case of the European Defence Community in France (1950-1954), in: French History, 1(2009), p.83; W. HITCHCOCK, France Restored ..., op.cit., pp. 190-197.

30. K. RUANE, op.cit., p.164; V. GAVIN, op.cit., p.87.

31. More precisely, Britain promised to retain its existing level of defence forces on the Continent and agreed not to withdraw them against the wishes of the majority of the Western European Union members. See NAA, A816, 19/301/701, London Conference on Germany: Note by the Office of the British High Commissioner in Canberra, 30.09.1954; see also K. RUANE, op.cit., p.176; S. DOCKRILL, Retreat from the Continent ..., op.cit., pp.49 and 52. London also pledged to continue to have its tactical air force assigned to the Supreme Allied Commander Europe (SACEUR). See NAA, A816, 19/301/701, Extract from Eden's Statement to the Nine Power Conference on 29 September 1954. See also NAA, A816, 19/301/701, Holmes to Menzies, 30.09.1954.

32. For Eden's comments see NAA, A816, 19/301/701, Decision to Keep Four Divisions and Air Forces on the Continent of Europe, 30.09.1954. For the historical implications of the British decision to make a long-term commitment to Continental security see A. DEIGHTON, Arming the Key Battleground: German Rearmament, 1950-1955, in: Diplomacy \& Statecraft, 2(1992), pp.348-349; S. DOCKRILL, Britain's Policy for West German Rearmament, op.cit.; S. DOCKRILL, Retreat from the Continent..., op.cit., p.49. Deighton has argued that the British decision 'was a radical shift for Britain's European strategy'. According to Dockrill, it had the effect of reorienting Britain further towards Europe. 
The collapse of the EDC came as no surprise to the Australian authorities and enticed no reaction from them. Yet, it is important to note that the whole EDC affair was not without potential consequences for Australia. The British pledge to maintain a long-term military presence on the Continent as a reassurance to France against Western German rearmament posed an awkward problem to Australian policymakers for it foreshadowed the possibility of Britain's growing involvement in Continental defence at the expense of its extra-European commitments. ${ }^{33}$ Although the Churchill government had been careful to stress that British troops in Continental Europe could be temporarily redeployed in other theatres in case of an emergency, Canberra was nonetheless concerned that this would be easier said than done once the commitment to European security had been made. ${ }^{34}$ In early October 1954, the Secretary of the Department of External Affairs, Arthur Tange, advised Foreign Minister Richard Casey to show caution on the European defence issue. 'If you have to say anything publicly', Tange told Casey, 'it would seem best to refer to great importance of security in Western Europe and earlier risk of disintegration rather than to say specifically whether we approve of Eden's commitment'. 'We have', he added, 'been concerned about whether this long-term commitment might prejudice the United Kingdom's military capacity in regions closer to Australia'. Tange regarded London's assurances that the long-term stationing of British defence forces on the Continent would neither affect British plans for the establishment of a Commonwealth strategic reserve in Malaya nor prevent the rapid redeployment of these forces outside Europe, as hardly adequate. ${ }^{35}$

From an Australian point of view, the problem was not that Eden's commitment amounted to greater British troop deployments on the Continent. The problem was rather that it could potentially tie down existing British forces in Europe at the expense of other theatres. ${ }^{36}$ Tange immediately approached the Department of Defence to see whether it 'was doing any sort of an appreciation of the implication of the United Kingdom decision' and even considered bringing the issue up with Menzies himself. ${ }^{37}$ In the end, Australian concerns over the aftermath of the EDC crisis subsided. Yet, the EDC affair highlighted how closely the security of the British Isles was bound to that of the Continent and how Britain's closer engagement with this region could

33. Britain's pledge responded to other foreign policy considerations too. On this point see A. DEIGHTON, Last Piece of the Jigsaw ..., op.cit., p.192.

34. British troops on the Continent could also be reduced if the cost of their deployment 'were to throw at any time too heavy a strain on the external finances of the United Kingdom'. NAA, A816, 19/301/701, London Conference on Germany: Note by the Office of the British High Commissioner in Canberra, 30.09.1954.

35. NAA, A816, 19/301/701, Australian High Commission (henceforth AHC) Ottawa to DEA, cablegram 181, 08.10.1954. For the British assurance see NAA, A816, 19/301/701, Holmes to Menzies, 30.09.1954; Department of External Affairs to Department of Defence, 07.10.1954. On the establishment of a Commonwealth Strategic Reserve in Malaya see P. EDWARDS, G. PEMBERTON, Crises and Commitments: The Politics and Diplomacy of Australia's Involvement in Southeast Asian Conflicts, 1948-1965, Allen \& Unwin, Sydney, 1992, pp.162-168.

36. NAA, A816, 19/301/701, Decision to Keep Four Divisions and Air Forces on the Continent of Europe, 30.09.1954.

37. NAA, A816, 19/301/701, Telephone Call from Tange. Note by Frederick Shedden, 06.10.1954. 
upset Australian defence calculations in the Far East. Of course, the question here was not of a British direct participation in a European supranational defence scheme, which, in any case, had proved unattainable; it was rather a question of a growing British involvement in the security of Western Europe - in other words, of a 'pull factor' that risked drawing Britain closer to its Continental partners.

\section{Australia and the EEC}

The EDC fiasco did not put a stop to new proposals for further Western European integration. In mid-May 1955 the Benelux governments produced a memorandum calling for the creation of an economic common market among the Six in the shape of a customs union. ${ }^{38}$ In June 1955 the Foreign Ministers of the 'Little Europe' gathered at Messina in Sicily to discuss the next steps in European integration. They agreed that while political integration remained the Six's long-term goal, priority be given to greater integration in the economic domain. An intergovernmental committee under the chairmanship of Belgian Foreign Minister Paul-Henri Spaak was set up. In April 1956, it produced a report recommending the creation of Euratom and a common market. The Spaak report was endorsed at the Venice conference in May 1956 and adopted as a starting point for the negotiation of two new European communities. Protracted consultations among the Six between May 1956 and March 1957 culminated in Rome with the signing of the treaty establishing the EEC and Euratom on 25 March 1957.

Australia's response to the Messina powers' common market initiative took time to develop. Canberra's initial attitude was to wait and see. After the EDC's collapse, the Menzies government was not only aware of the arduous task facing the Six as they attempted to re-launch the integration process, but it was also sceptical of the feasibility of grandiose integrationist Continental schemes. The fact that London remained opposed to joining supranational Western European bodies, provided further reassurance that political and economic developments on the Continent posed no immediate threat to Australian interests. Ministers, therefore, began to examine the Messina powers' initiative only in late October 1956. The opportunity was provided by a British proposal aimed at creating a European free trade area in industrial products which would be open to all OEEC members, including the Six. ${ }^{39}$ The prospect of British association with the Six in the economic and trade field naturally drew ministerial attention in Canberra. While expressing caution about the economic implications of a free trade area for Australia, Menzies and his ministers were supportive of British plans to discuss this project with the Six on condition that agricultural

38. W. KAISER, op.cit., p.23; see also W. HITCHCOCK, The Struggle for Europe: The Turbulent History of a Divided Continent, 1945 to the Present, Anchor House, New York, 2003, pp.154-155.

39. For the origins of the Plan G see M. SCHAAD, Plan G: A "Counterblast"? British Policy towards the Messina Countries, 1956, in: Contemporary European History, 1(1998), pp.39-60. It should be mentioned that the free trade area project excluded farm produce. 
produce would not be part of the equation. As farm commodities constituted the great bulk of Australia's exports to Britain under the imperial preference system, Canberra had no interest in seeing Australian access to the British market curtailed as a result of an Anglo-European free trade area.

As for the Six's common market initiative, ministers took a benevolent view of it and said that they were 'conscious of the important political and economic advantages which could flow from a strong and united Europe' ${ }^{40}$ It is true that Acting Minister for Trade William McMahon warned his ministerial colleagues of the potential risks arising from the customs union proposal - namely the introduction of a common external tariff, which could 'conform to the highest rather than the lowest level of existing tariffs', and the adoption of restrictive trade regulations in the agricultural sector. Yet, in late 1956, even the Department of Trade (DT), which was destined in the years to come to become a vocal critic of the EEC's trade practices in the agricultural field, approved of the Six's efforts to achieve closer political and economic co-operation in Western Europe, arguing that their initiative would not only boost their international stature, but would also settle the German question once and for all. ${ }^{41}$ It was nonetheless clear that ministerial support for both the British and European initiatives was conditional upon London's pledge not to become too closely involved in the Six's ambitious designs. As long as Britain remained opposed to supranational schemes, the Menzies government could afford to take a rather magnanimous approach towards greater Continental integration.

But, as events were soon to show, Australian support for Western European integration was to be highly qualified. In early 1957 , as the Six moved closer to a final agreement, the Menzies government became alarmed at reports that under French pressure the Six were canvassing treaty arrangements for the creation of a protected internal market for agricultural commodities. ${ }^{42}$ All of sudden, the Australian attitude hardened and departments in Canberra began to take a closer look at developments on the Continent. On 2 February 1957 Minister for Trade John McEwen handed a stern note to the Six registering Australian concern at their proposed arrangements on agriculture. ${ }^{43}$ In it, McEwen made it clear that while appreciating the economic and political case for closer European co-operation, Canberra remained uneasy about the introduction of protectionist agricultural provisions in the final customs union treaty. He warned the Six that

'Australia would be bound to oppose within GATT any proposal for the extension to the Customs Union as a whole of any system of agricultural marketing or price support involving non-tariff regulation of competing imports now maintained on a national basis in any one country of the Messina group' ${ }^{44}$

40. NAA, A4906, vol.18, Cabinet decision 546, 30.10.1955.

41. Ibid., Cabinet submission 444, 30.10.1956.

42. NAA, A1838, 971/4/11 part 1, DEA to AHC London, 22.01.1957; DEA to Paris, 22.01.1957; AHC Ottawa to DEA, 17.01.1957.

43. See NAA, A1209, 1957/4595 part 1, European Common Market: note by Brennan, 04.02.1957.

44. NAA, A1209, 1957/4595 part 1, Aide Memoire, 02.02.1957. 
Following the signing of the Treaty of Rome on 25 March 1957 and the inclusion of potentially protectionist agricultural provisions in the treaty itself, McEwen reiterated his criticism..$^{45}$ In early April, he recommended to Cabinet the following course of action: first, the government should seek 'maximum action in GATT prior to ratification (as distinct from signature) of the Treaty and subsequently'; second, it should exert significant pressure on the Six to ensure that they took the interests of non-EEC agricultural producers into account; third, it should try 'to enlist as much support as possible for our position from USA, Canada and the UK in GATT and by other means for modification or adjustment of them' ${ }^{46}$ Australia's aim was not only to safeguard its existing agricultural trade with the Six, which McEwen put at about A£ 18.5 million a year, but also to open up additional trade opportunities. ${ }^{47}$

McEwen's diplomatic approach soon ran into difficulties. Despite Australian attempts to seek an early examination of the Treaty of Rome within GATT, the GATT Intersessional Committee decided at the end of April 1957 that further preparatory work was needed before an effective examination of the Treaty could be made. The United States and Canada argued that any special session of the GATT on the Treaty of Rome should be deferred until the ratification process was completed in the parliaments of the Six. The American and Canadian view was that 'intensive discussion of the Treaty in GATT could embarrass the Messina Governments, and hinder the ratification procedures' ${ }^{48}$ The Eisenhower Administration, in particular, was strongly supportive of the Messina initiative ${ }^{49}$ Despite sharing some of Australia's economic concerns, the Administration was inclined to brush them aside on the altar of greater Western European cohesion. Political motives clearly overrode American anxieties about the Six's protectionist tendencies in agriculture. And, in any case, the reality was that while the promise of an integrated agricultural policy was indeed a concern for the Americans, the actual legal stipulations on agriculture contained in Treaty of Rome were rather weak and sketchy. Hence, there would still be plenty of scope, the American Administration believed, for the United States and other inte-

45. For a detailed discussion of the articles (38-47) of the Treaty of Rome relating to agriculture see R. FENNELL, The Common Agricultural Policy of the European Community: Its Institutional and Administrative Organisation, BSP Professional Books, Oxford, 1987, pp.7-10.

46. NAA, A571, 1959/2383 part 2, Cabinet submission 577, 21.03.1957.

47. Ibid., Treasury's note on Cabinet submission 577, European Common Market, 26.03.1957.

48. NAA, A1838, 791/4/11 part 4, Maris King to Arthur Tange, 13.05.1957; NAA, A1838, 791/4/11 part 2, AHC Ottawa to DEA, cablegram 72, 15.03.1957.

49. P. WINAND, Eisenhower, Kennedy, and the United States of Europe, St. Martin's Press, New York, 1993, chapter 5; see also G. WARNER, Eisenhower, Dulles and the Unity of Western Europe, 1955-1957, in: International Affairs, 2(1993), pp.320-324. 
rested nations to influence the Six's policymaking on agriculture in the years to come..$^{50}$

Hence, despite McEwen's repeated attempts in 1958 to bring the Treaty of Rome to the attention of the GATT, his strategy paid no dividends. The GATT was unwilling to challenge the EEC and 'took refuge behind procedural and technical barriers'. ${ }^{51}$ Representations to EEC governments also brought McEwen little joy. While some European governments such as West Germany were not unsympathetic towards Australian agricultural concerns, they were unwilling to endanger EEC's cohesion to accommodate Australian claims. What is more, the Six found McEwen's criticism of the agricultural aspects of the Treaty of Rome a little hypocritical given that, with the exception of agriculture, Australia was at the time one of the most protectionist countries in the Western world. ${ }^{52}$ As for Britain, the Macmillan government advised Canberra to seek protection through the GATT. ${ }^{53}$

John O'Brien has argued that McEwen's diplomatic strategy, at least initially, 'was to have it [the EEC] dismantled'. ${ }^{54}$ This is an exaggeration not supported by archival evidence. In September 1957 McEwen made it clear to Cabinet that it was not the Australian government's intention to 'wreck' the EEC. ${ }^{55}$ But while this is no doubt the case, it is also clear that the Menzies government was not prepared to go as far as the Americans in supporting the creation of a strong economic Western European entity, especially if this meant incurring some trade losses. ${ }^{56}$

One reason for Australia's conditional support was that whereas the Americans had a significant stake in the security and prosperity of the Continent, and saw the strengthening of Western Europe as a political imperative in the containment of the Soviet Union, Australian interests in Western Europe were more tenuous and, thus,

50. On the question of the agricultural regime envisaged by the Treaty of Rome see N.P. LUDLOW, The Making of the CAP: Towards a Historical Analysis of the EU's First Major Policy, in: Contemporary European History, 3(2005), pp.349-350. It is worth noting that a further factor contributed to the Administration's soft attitude towards the Messina powers: the Americans themselves were not alien to agricultural protectionism and had hitherto prevented any meaningful discussion of it within the GATT with the result that agriculture remained outside the GATT system. On this point see D. KENYON, D. LEE, The Struggle for Trade Liberalisation in Agriculture: Australia and the Cairns Group in the Uruguay Round, Department of Foreign Affairs and Trade, Canberra, 2006, pp.9-10.

51. J. O'BRIEN, Australian Department of Trade ..., op.cit., p.41.

52. According to A. Woodland, Australia 'entered the 1950s with a half-century history of increased protection of its manufacturing sector [...]. The basis for the protection policy was provided by the United Kingdom-Australia Trade Agreement of 1932, which firmly established the principle that tariffs would be set to compensate for cost disadvantages suffered by domestic Australian manufacturers relative to their British competitors'. A. WOODLAND, Trade policies in Australia, in: S. DOMINICK (ed.), National Trade Policies: Handbook of Comparative Economic Policies, Greenwood Press, Westport, 1992, p.239.

53. D. GOLDSWORTHY, op.cit., p.158.

54. J. O'BRIEN, Australian Department of Trade ..., op.cit., p.41.

55. NAA, A4926, Cabinet submission 862, 17.09.1957.

56. On the Eisenhower Administration's pro-integration stance see P. WINAND, op.cit.; see also G. WARNER, Eisenhower, ..., op.cit., pp. 319-329. 
harder to define. Throughout 1957 and afterwards, Australian ministers and officials would repeatedly stress the political and economic importance of closer Continental co-operation, yet they would continue to find it difficult to spell out how exactly Australia would benefit from it. Thus, it was no surprise that while somewhat vague about the supposed benefits of Western European integration for Australia, they were under no doubt that the broad political merits of the common market project should be weighed against its commercial demerits.

The other, and perhaps more important, reason for this ambivalent attitude was the tight grip exerted by the Department of Trade (DT) over governmental policy with regard to European integration. Under the leadership of the influential and powerful McEwen, the DT tended to monopolise official thinking on this issue and hijack the policymaking process. In this Trade was supported by the Department of Primary Industry, who was also worried about the Six's attempts to establish a protectionist trade regime. As for the Treasury, this influential department, while critical of the DT, was not prepared to challenge the latter's ascendancy. Nor were Canberra's political departments - External Affairs and the Prime Minister's Department (PMD). Of the two, the PMD was the greatest critic of Trade's increasing hard-line stance towards the EEC. The PMD argued that European integration, while undoubtedly presenting some costs for Australia, needed not be, on the whole, harmful to Australian economic interests. ${ }^{57}$ In fact, trade losses deriving from the introduction of a common external tariff and a regulated domestic agricultural market would be minimal. The PMD was concerned that Trade's line 'was too narrow' and that if Australia 'continued to be wholly preoccupied with the particular considerations for our export trade, events would likely to pass us by'. ${ }^{58}$ But the PMD's efforts to bring some balance into Australian policy over Europe were hampered by the Prime Minister himself. In 1957 Menzies appeared closer to McEwen's thinking than that of his departmental officials. ${ }^{59}$ As for External Affairs, it was still a small department with limited expertise on economic affairs.$^{60}$ His minister, Richard Casey, carried little influence in Cabinet and DEA officials, unlike their counterparts in the PMD, appeared to take a somewhat less sanguine attitude towards Western European integration.

57. NAA, A1209, 1957/5119 part 2, Lawler to Bunting, 13.06.1957; see also The European Economic and the Proposed Free Trade Area - Considerations for Australia, PMD note, June 1957.

58. NAA, A1209, 1957/5119 part 1, Lawler to Bunting, 02.07.1957.

59. NAA, A1838, 791/4/11 part 6, Statement by Menzies to the Liberal Party Federal Council, Canberra, 21.10.1957

60. On this point see Maris King and Michael Wilson, Interview with Maris King, http://nla.gov.au/ nla.oh-vn569002. 


\section{Conclusion}

Throughout the 1950s the Menzies government maintained an ambivalent attitude towards Western European political and economic integration. In general, it supported its political objectives. Yet it remained apprehensive of the economic implications of greater European integration for Australian trade despite the fact that, in the late 1950s, Australia did not stand to lose too much from it. In 1955-56 the value of Canberra's exports likely to be affected by the creation of a Western European customs union was only A£ 18.5 million, that is approximately 2.3 per cent of Australia's overall exports worth $A £ 770$ million. ${ }^{61}$ Canberra's focus on the economic, rather than political, aspects of Western European integration was attributable not only to the priority given by the Six themselves to economic integration, but also to the DT's increasing hold on Australia's Europe policy. With McEwen in charge of Australia's diplomacy towards the Messina powers, it was inevitable that the Australian approach to Western European integration would be less sympathetic than it could have otherwise been. Canberra's concerns, however, were not solely economic. Australian policymakers were also nervous about the possibility of closer British political collaboration with the Six. As mentioned above, Britain's long-term commitment to Western European security following the collapse of the EDC raised concerns in Canberra as it seemed to indicate - despite British assurances to the contrary - a diminished capacity on Britain's part to intervene militarily outside Europe.

The Australian attitude, of course, would become more negative in August 1961 when the Conservative government of Harold Macmillan announced its intention to negotiate Britain's entry into the EEC. The British decision, which came as a shock to Menzies and his ministers, would be seen as a serious blow to Australia's political, economic and strategic interests and would negatively colour Australian perceptions of the EEC. At a political level, British entry was thought likely to undermine Britain's historical ties with Australia and the Commonwealth. As External Affairs would put it in a June 1961 submission to Cabinet, London's membership of the EEC was bound to disturb 'the whole complex of relationships, including the Commonwealth, on which Australia's traditional outlook and politics rests' ${ }^{62}$ At an economic level, entry would have significant repercussions for Australia's trade with Britain. McEwen would waste no time to highlight the fact that some A£ 140-150 million, or 55-60 per cent of Australia's exports to the British market, could be affected depending on the nature of Anglo-European agreement. ${ }^{63}$ At a strategic level, British entry was expected to curtail London's freedom of action as a world power and weaken its resolve to play a politico-military role in the Far East where Australia's main strategic interests lay. ${ }^{64}$ All of sudden, Western European integration appeared to be an unmitigated disaster for the Menzies government. Long gone were the government's

61. NAA, A571, 1959/2383 part 2, Treasury's note on Cabinet submission 577, European Common Market, 26.03.1957.

62. NAA, A1838/269, TS899/1/4 part 2, Cabinet submission 1183, 26.06.1961.

63. NAA, A1838/283, 727/4/2 part 1, Cabinet submission 1108, 05.05.1961.

64. NAA, A1838/269, TS899/1/4 part 2, Cabinet submission 1183, 26.06.1961. 
support for the ECSC and its timidly benevolent attitude towards the recently established EEC. The stage was now set for three long decades of Australian-European misunderstandings. 